\title{
READING LITERACY WITH THE SUPPORT OF INFORMATION AND COMMUNICATION TECHNOLOGY
}

\author{
Martina FASNEROVÁ
}

\begin{abstract}
The paper deals with the development and literacy skills in the Czech Republic by pupils at primary schools in relation to the current curriculum. It points the need for the usage of information and communication technologies for development of reading and general development of functional literacy. The research is carried out through a questionnaire survey and structured interview with teachers.
\end{abstract}

Key words: Literacy, reading literacy, information literacy, communication technology, basic school, elementary class, a teacher, a research, questionnaire, interview.

\section{ČTENÁŘSKÁ GRAMOTNOST S PODPOROU INFORMAČNÍCH A KOMUNIKAČNÍCH TECHNOLOGIÍ}

Resumé: Příspěvek se zabývá rozvojem a úrovní čtenářské gramotnosti v České republice u žáků prvního stupně základních škol v návaznosti na současné kurikulární dokumenty. Zdůrazňuje potřebnost využití informačních a komunikačních technologií pro rozvoj čtenářství a všeobecný rozvoj funkční gramotnosti. Výzkumná sonda je realizována prostřednictvím dotazníkového šetření a řízeného rozhovoru s učiteli.

Klíčová slova: gramotnost, čtenářská gramotnost, informační gramotnost, komunikační technologie, základní škola, elementární třída, učitel, výzkumná sonda, dotazník, rozhovor.

\section{1 Úvod}

Český jazyk a matematika tvoří jedny z piliřů základního vzdělávání. Matematika je řazena do oblasti Matematika a její aplikace a český jazyk do oblasti Jazyk a jazyková komunikace. Přesto, že se mnozí domnívají, že tyto dva předměty, potažmo tyto dvě oblasti nemají vůbec nic společného, opak je pravdou.

Prostřednictvím těchto dvou předmětů žáci získávají všeobecný přehled o některých pojmech, se kterými se $\mathrm{v}$ jiných oblastech nesetkali, a to zejména proto, že výuku obou předmětů lze podpořit prostřednictvím informačních a komunikačních technologií.

V kontextu kurikulární reformy se stále častěji setkáváme s pojmy, jako je čtenářská gramotnost, funkční gramotnost, matematická gramotnost i počítačová gramotnost. Dané pojmy jsou v současném vzdělávání velmi důležité nejen svým obsahem, ale také formou, prostřednictvím které žáci docílí dalšího úspěchu ve vzdělávání.

$\mathrm{K}$ tomu, abychom se orientovali $\mathrm{v}$ pojmu čtenářská, matematická, počítačová gramotnost je velmi důležité vysvětlit pojem gramotnost jako pojem základní a obecný. Jak je zřejmé, jedná se o poměrně komplexní jev, a proto dochází $\mathrm{k}$ jeho elementarizaci. Nelze se takto vyhnout určitému zjednodušení. Obecně lze konstatovat, že nejvýznamnější roli $\mathrm{v}$ definování samotného pojmu „gramotnost“" sehrálo UNESCO. Podílelo se na vypracování a posléze na přijetí definice gramotnosti na 10 . zasedání Valného shromáždění ve znění:

„Gramotný člověk je takový, který umi s porozuménim prečist a napsat krátký jednoduchý výrok ze svého každodenního života" (UNESCO, 1958, s. 16).

Podle Pedagogického slovníku (Průcha, Walterová, Mareš, 2009, s. 85) je gramotnost: „Dovednost jedince čist, psát a počitat ziskávána obvykle v počátečnich ročnicich školni docházky. V tomto smyslu jde o ,základni gramotnost“, která je predpokladem jak dalšiho vzdělávání, tak vůbec uplatnèní jedince ve společnosti. "

Ve vyspělých zemích je samozřejmě gramotnost na vysoké úrovni a disponuje gramotností většinou celá společnost. Naopak v málo vyspělých zemích dochází k výskytu gramotnosti pouze u $40 \%$ obyvatelstva. $\mathrm{V}$ takovém př́padě se setkáváme s pojmem negramotnost.

Vyšší úrovní než je jen gramotnost je funkční gramotnost, z anglického functional literacy, což ve volném překladu znamená získání potřebných kompetencí a vybavenosti člověka na takové úrovni, na které by byl schopen realizovat různé 
aktivity, a tím byl potřebným a aktivním členem dané společnosti.

Výstižně shrnuje dosavadní poznatky o gramotnosti Doležalová (2005, s. 14), která uvádí, že ,gramotnost znamená ovládnuti různých druhů komunikace za účelem začleněni jedince $v$ dané společnosti, pro jeho uspokojivé konáni a bytí ve prospěch svůj i druhých. Jedná se o schopnost, která mu umožní rešit proměnlivé problémy denního života. ... $V$ modernich civilizacich zahrnuje gramotnost základní a vyšši stupně gramotnosti. “

Je velmi důležité pochopit, že vzdělávání žáků i v oblasti gramotností musí být promyšlené a systematické. Dlouhodobé výsledky úrovně čtenářských dovedností našich žáků v mezinárodních výzkumech jsou, jak víme, neutěšené.

Na tomto místě je velmi aktuální zmínit i pojem počítačová gramotnost, kterým se základní školství začalo intenzivněji zabývat v souvislosti $\mathrm{s}$ platnými kurikulárními dokumenty. Podle Pedagogického slovníku (Průcha, Walterová, Mareš, 2009, s. 204) se jedná o základní součást novodobé vzdělanosti každého člověka. „Zahrnuje soubor vědomosti o možnostech a mezich počitačů, počitačových sití i nejčastějšího programového vybaveni ".

Jestliže se budeme dále držet výkladu prostřednictvím Pedagogického slovníku, lze konstatovat, že potřebujeme u žáků již v nejútlejším věku vytvořit soubor určitých návyků, ale zároveň vědomostí a dovedností, tedy kompetencí, které jsou bezprostředně nutné k obsluze počítačů a internetu. Počítačová technologie pak žákům umožní efektivněji využívat informace i $v$ jiných předmětech a oblastech pro další základní vzdělávání i mimoškolní vzdělávání, potažmo počítá s využitím informačních technologií i v profesním životě.

\section{Současný stav řešené problematiky}

Jak uvádí zpráva Výzkumného ústavu pedagogického v Praze v roce 2011, žáci se velmi zhoršili v úrovni čtenářských kompetencí. Jedná se o jednu z hlavních kompetencí, kdy při jejím nenaplňování jsou žáci znevýhodňováni i v jiných předmětech a oblastech naprríc současným kurikulem. Z těchto indicií se lze zamýšlet nad faktem, zda kurikulum v podobě RVP ZV je nastaveno správně a jestli $v$ této oblasti nedochází $\mathrm{k}$ varování při zpracovávání ŠVP. Jedná se především o to, že žáci by měli být připraveni na další typ vzdělávání získáváním a naplňováním klíčových kompetencí a vybaveni tak nejen pro celoživotní vzdělávání, ale zejména uplatnitelnost na trhu práce. Varovné výsledky v oblasti čtenářské gramotnosti nezaručují žákům úspěšný život, ani to, že budou konkurenceschopní na trhu práce.

$\mathrm{Z}$ těchto důvodů se domníváme, že s rozvojem čtenářství a následně $\mathrm{s}$ vytvářením potřeby číst se děti musí seznámit již v co nejútlejším věku. Jedná se samozřejmě o individuální př́stup ke každému jedinci, posuzované mírou jeho schopností a dovedností v dané oblasti. Hledáme také takové motivační aspekty, které by zaručily pozitivní vztah kučení u žáků. Takovým didaktickým prostředkem se jeví počítačové technologie, jako nový komunikační zdroj, již od útlého dětství.

Již v elementární třídě základní školy, kdy se žáci učí číst a psát, dochází $\mathrm{k}$ vytváření nejen znalostí a dovedností, ale především $\mathrm{k}$ tvorbě postojů a zkušeností, tedy $\mathrm{k}$ vytváření klíčových kompetencí definovaných v RVP ZV (Jeřábek, Tupý, 2005). Je potřeba si v této souvislosti uvědomit, že břemeno utváření klíčových kompetencí u žáků je v počátečním vzdělávání zejména na učitelích elementaristech, kteří učí žáky nejen technice čtení a dovednosti psaní, pro snazší získávání informací, ale především proto, aby se žáci prostřednictvím čtení uměli orientovat v lidské kultuře a hodnotách daného národa.

S rozvojem čtenářské gramotnosti je nutné začít již v elementární třídě základní školy a v jisté formě již v předškolním vzdělávání, jak nám ukazují výsledky různých analýz. Jedná se totiž o celoživotní a neustále se rozvíjející proces. Proto je potřebné ho uchopit a pracovat s tímto cílem již od nejútlejšího věku dítěte. Pokud bude s touto problematikou správně nakládáno i v dospělosti, bude u jedinců pokračovat potřeba jejího rozvoje. $\mathrm{K}$ této problematice se vyjádřila i Wildová (2005), která hovoří i o jednotlivých modelech pro zkvalitnění výuky čtení tak, jak nám to ukazuje zahraniční zkušenost napřr. z Velké Británie.

Jednu z nejdůležitějších rolí v oblasti a rozvoji čtenářské gramotnosti sehrává učitel. Učitel zprostředkovává informace žákům, ale zejména výběrem vhodných textů používá i takové výukové strategie, které jsou pro žáky daného věku nejefektivnější a nejpřiměřenější.

Učitel musí vycházet $\mathrm{z}$ faktu, že všechno se žáci ve škole nedozvědí. V současné době je $\mathrm{k}$ dispozici velká řada informací a poznatků, z čehož vyplývá, že hlavním úkolem ve 
vzdělávání by mělo být naučit žáky informace vyhledávat a pracovat s nimi. I tuto dovednost a kompetenci by však měl učitel své žáky učit. Ve škole by se měl žák naučit rychle se dozvědět, co ho právě zajímá a co potřebuje vědět. Tuto dovednost by se měli učit žáci již $\mathrm{v} 1$. tř́dě základní školy prostřednictvím učitele elementaristy. (Fasnerová, 2012)

$Z$ těchto poznatků můžeme také vyvodit skutečnost, že v elementární tř́dě nezastupitelnou roli tvoř́i i motivace žáka. Učitel by měl vyhledat u žáků směr jejich zájmů a jejím prostřednictvím prohlubovat a rozšiřovat kompetence směřující $\mathrm{k}$ využití informačních technologií. Získané elementární dovednosti $\mathrm{v}$ oblasti počítačových technologií na mnohých školách získávají žáci již v elementárních třídách, zejména tehdy, je-li ŠVP tímto směrem orientován. Informační technologie jsou nezastupitelným prostředkem pro získávání informací do všech vzdělávacích oblastí z celého světa.

V elementární tř́idě je nezbytné, aby docházelo k rozvoji nejen techniky ve čtení, ale zároveň $\mathrm{k}$ vytváření pozitivní a vnitřní motivace $\mathrm{k}$ potřebě číst. Velmi záleží na osobnosti učitele elementaristy, který v mladším školním věku žákům zprostředkovává informace vedoucí $\mathrm{k}$ čtenářské gramotnosti. Tuto činnost lze žákům zprostředkovat i prostřednictvím počítačů. Záleží na jeho individuálním př́stupu $\mathrm{k}$ jednotlivým žákům, ale také na tom, jak on sám je vybaven znalostmi a dovednostmi dané problematiky. Velkou roli sehrávají metody a formy, ale také celé vyučovací strategie, které pro rozvoj čtenářství učitel volí a používá. I zde se nabízí využití počítačů a interaktivních tabulí, jako významného motivačního a zároveň didaktického prostředku pro žáky. Jestliže učitel sám má o čtení velký zájem a je kladně motivován pro rozvoj čtenářských kompetencí, dokáže také snadněji svým žákům tuto činnost zprostředkovat.

Pro rozvoj čtenářství je nutné mít každou vyučovací hodinu dobře promyšlenou, nebot' nejnáročnější je výběr textů, které učitel pro výuku zvolí. Vhodně vybraný text, který čtenáře pozitivně osloví u nich navodí potřebu číst. Proto nelze texty vybírat nahodile, ale s přihlédnutím $\mathrm{k}$ věku dětí. Vzhledem $\mathrm{k}$ tomu, že $\mathrm{v}$ rozvoji čtenářské gramotnosti, jak je zřejmé z úvodu př́spěvku, nejde jen o převypravování textu, ale o získávání informací a práce s textem, je na učiteli zvolení i takových literárních žánrů, které jsou pro žáky vhodné, ale i zajímavé, aby při jejich rozboru mohli zažít pocit úspěšnosti ze zadaného úkolu. Velký důraz by měl být kladen také na žáka, tedy aby si texty pro svou práci a rozvoj volil sám. Preference vlastní knihy, vyhledávání vlastních textů a porovnávání svých zájmů o četbu se zájmy svých vrstevníků vedou k pozitivní motivaci žáka a $\mathrm{k}$ jeho aktivní činnosti na tvorbě vyučovací hodiny.

V poslední době je velmi aktuální zavádění interaktivních učebnic do výuky. Některá nakladatelství pružně zareagovala na současnou politiku ve vzdělávání a snaží se jak pro žáky, tak pro učitele připravit učebnice nejen $\mathrm{v}$ podobě tištěné, které jsou neodmyslitelnou součástí výuky zejména v elementární třídě, ale i učebnice interaktivní, které však vyžadují, aby byla třída vybavena interaktivní tabulí. Na českém trhu se objevuje velká nabídka interaktivních tabulí a prodejci vytváríi pro školy finanční programy, na základě kterých se mohou školy zapojit do různých aktivit a tím získat finanční prostředky na zakoupení ne jedné, ale více interaktivních tabulí. Ideálním stavem se v současné době jeví to, aby každá trŕda měla instalovanou svoji interaktivní tabuli, a to již od elementárního ročníku. $O$ vybavenost tříd interaktivními tabulemi projevují zájem i učitelky mateřských škol, které svou výuku čtenářské gramotnosti realizují rovněž prostřednictvím interaktivní výuky. Učitelé mají možnost seznámit se již s hotovými produkty, které jsou jim nabízeny $\mathrm{v}$ této oblasti, ale rovněž se zapojit do vytváření interaktivní výuky sami, prostřednictvím školení, která jsou jim nabízena firmou při zakoupení a instalaci interaktivní tabule.

Vzhledem $\mathrm{k}$ tomu, že se $\mathrm{v}$ našich školách neustále klade velký důraz na řízení vyučovací jednotky učitelem, zaměřili jsme se ve své výzkumné sondě na učitele a na jejich znalosti či zkušenosti s rozvojem čtenářské gramotnosti a dotkli jsme se i v této souvislosti používání didaktických prostředků $\quad-$ informačních technologií.

\section{Výzkumná sonda - dotazníkové šetření}

Cílem dotazníkového šetření bylo zjistit postoj učitelů elementaristů, tedy učitelů, kteř́ vyučují v 1. trrídách základních škol, ke čtenářské gramotnosti. Vzhledem k tomu, že již v 1. tř́́dách ZŠ je nutné, $z$ našeho pohledu, se touto problematikou zabývat, nebot' nejde jen o učení správné techniky čtení, nýbrž o vytváření dovedností a postojů $\mathrm{v}$ oblasti čtenářské gramotnosti obecně, jak jsme již popsali. Jedna z otázek se také týkala nových komunikačních 
a informační technologií v souvislosti s gramotností žáků i učitelů.

Učitelům, kteří učí $\mathrm{v}$ prvních třídách olomouckého kraje, byl předložen dotazník s 11 položkami, prostřednictvím kterých bylo zjišt'ováno, jestli se orientují $\mathrm{v}$ problematice čtenářské gramotnosti. Dotazník byl doplněn rozhovorem s učiteli.

Z výsledků šetření vyplynulo, že se učitelé elementaristé s pojmem čtenářské gramotnosti setkali v 30, $6 \%$ na některém ze školení, které záměrně v tomto oboru navštívili. Ve $38,7 \%$ o dané zkušenosti pak informovali své kolegy ve škole. Domníváme se, že toto poměrně vysoké \% učitelů, kteří mají o problematice povědomí je způsobeno informovaností a alarmující skutečností, která se $\mathrm{v}$ poslední době $\mathrm{v}$ našem školství odehrává. Nebot' jsme si vědomi nedostatků ve výsledcích našich žáků, ředitelé základních škol s největší pravděpodobností naléhají na učitele (i učitele elementaristy), aby se vzdělávali prostřednictvím kurzů a v problematice gramotnosti se více orientovali. Přesto nás zaráží skutečnost, že $11,3 \%$ učitelů se s pojmy gramotnosti ještě nesetkali.

Další položky v dotazníku se zabývaly tím, zda byli učitelé seznámení s vyučovacími strategiemi, které rozvíjí čtenářskou gramotnost a zda tyto nové strategie aplikují také v praxi.

Výsledky šetrení byli zajímavé, nebot' 78\% učitelů elementaristů se účastnilo vzdělávání se záměrem nejen obohatit své zkušenosti a dosavadní znalosti, ale zejména naučit se novým efektivnějším a účinnějším strategiím ve vzdělávání ve výše zmíněné oblasti. Nyní je však otázkou, zda své dovednosti, které získali ve vzdělávání, uplatní také $\mathrm{v}$ praxi. Měli by volit takové metody, které právě čtenářskou gramotnost rozvíjí.

Musíme si na tomto místě položit otázku, zda nejsou jen vybaveni učitelé novými poznatky, ale zda je také dokážou použít v praxi a zda jsou vybaveni aplikační dovedností do praxe.

Z dalších výsledků je zřejmé, že se učitelé stále fixují $v$ rozvoji čtenářské gramotnosti $\mathrm{z}$ velké části na předmět Český jazyk, a to v $76 \%$. Je také s podivem, že ve výčtu předmětů (jsme stále u učitelů elementaristů) se zaměřují pouze na naučné (výukové předměty- prvouka, matematika). Respondenti vůbec nezmiňovali předměty uměleckého charakteru (hudební, výtvarná výchova...) i jiného zaměření. Je zarážející skutečnost, že $\mathrm{v}$ případě, že učitelé se domnívají, že se vdané oblasti vzdělávají a poměrně dobře orientují, výsledek uplatnění v praxi je pak opět zaměřený na výuku a předávání informací. $\quad Z$ těchto výsledků vyplývá, že zřejmě učitelé dostatečně pojem čtenářské gramotnosti nechápou.

Z výsledků šetření je také zřejmé, že učitelé elementaristé používají metody pro rozvoj čtenářské gramotnosti, o kterých se domnívají, že ji prostřednictvím těchto metod rozvijí, ale skutečnost je jiná. Napríklad metody jako je doslovná reprodukce textu, výklad nebo recitace $\mathrm{z}$ našeho pohledu čtenářskou gramotnost nerozvíjí a přitom ji učitelé zařazují téměř ve 37 \%. Zatímco čtenářské portfolio a ostatní metody zatím učitelé používají velmi sporadicky. Lze konstatovat, že právě u metod, jako je skládankové čtení, čtení s otázkami, nebo čtení s předvídáním čtenářskou gramotnost velmi rozvijí, ale hlavně učí již malé čtenáře zamýšlet se nad textem a číst s porozuměním, tedy připravují se prostřednictvím těchto metod na využívání informací $\mathrm{z}$ textu a to ve čtenářské gramotnosti jde zejména.

Nejvyšší podíl na výběru textů pro rozvoj čtenářské gramotnosti ve škole má opět učitel, a to $\mathrm{v} 84 \%$, potažmo $\mathrm{v} 91 \%$. Ostatní subjekty, které do výuky také vstupují, se podílí na výběru ve velmi malé míře. Lze tedy konstatovat, že na průběhu vyučování se opět nic nezměnilo. Ani změnou kurikula, které $\mathrm{v}$ současné době umožňuje větší podíl žáků a rodičů na výuce. Jen ve velmi malé míře odpověděli učitelé, a to pouze v $9 \%$, že výběr textů konzultují s dětmi. Jak může být žák motivován pro rozvoj čtenářské gramotnosti, když musí pracovat pouze $\mathrm{s}$ materiálem, který je mu předkládán. Ani rodiče se nemají možnost na výběru textů podílet. Jak ukazují výsledky dalších otázek, tato skutečnost se jen potvrzuje.

Ve výzkumné sondě jsme se zabývali i použiváním informačních technologií při výuce čtení, jako zdroj informací pro své žáky. Museli jsme však konstatovat, že pouze v $17 \%$ se učitelé prvních tř́d zaměřují se svými žáky na vyhledávání informací prostřednictvím počítačů. U ostatních učitelů jsme se nesetkali s pozitivní reakcí na daný didaktický prostředek.

Je nutné přiznat i fakt, že učitelé elementaristé mají sami problémy s vyhledáváním informací prostřednictvím informačních technologií a počítačovou gramotnost nechápou jako jednu z nejdůležitějších kompetencí, kterými by žáky měli vybavit pro další efektivní a úspěšné vzdělávání, jak vyplynulo z rozhovoru s učiteli.

Také práce s interaktivní tabulí dělala učitelům problémy. Přiznali, že interaktivní 
výuky využívají málo, pouhých $6 \%$ učitelů si připravuje výuku na interaktivní tabuli v primární škole, přesto, že i ostatní ji mají instalovanou ve tř́idě.

Další položky byly zaměřeny na podněcování rodičů $\mathrm{k}$ podpoře čtenářské gramotnosti u svých dětí $\mathrm{v}$ rodinném prostředí.

Z výsledků vyplynulo, že učitelé elementaristé informují rodiče o rozvoji čtenářské gramotnosti velmi málo. Pouze na třídních schůzkách nabádají rodiče $\mathrm{k}$ důsledné kontrole, která se týká zejména techniky čtení a k pravidelnosti ve čtení. Tato činnost, zejména u prvopočátečního čtení je pro rodiče velkým problémem, nebot' svému dítěti, bez předchozích instrukcí, jak s dítětem pracovat, nemohou pomoci.

Také se jeví jako nedostačující fakt, že učitel nekontroluje a nepodněcuje $\mathrm{k}$ rozvoji čtenářstvî žáka v domácím prostředí, a to metodami, které by mu byly př́jemné, ale zároveň nezastupitelné. Daleko snadněji by docházelo k vytváření potřeby dítěte, potažmo žáka číst a získávat informace $\mathrm{z}$ textu. Zaváděním čtenářských deníků nepodněcujeme žákovu iniciativu číst, ba právě naopak.

Učitelé elementaristé se vyjadřovali velmi spontánně k tomu, že i volba základní výukové metody může ovlivnit rozvoj čtenářské gramotnosti. Velmi mnoho učitelů vyučuje na základní škole metodou analyticko-syntetickou, jak vyplývá i z procentuálního zastoupení $79 \%$. Lze však konstatovat, že i učitelé, kteři zkoušeli vyučovat podle metody globální, se později vrátili k výuce metodou analyticko-syntetickou, a to $\mathrm{z}$ několika důvodů. Jak vyplynulo $\mathrm{z}$ rozhovoru vedeného po informacích, zaznamenaných v dotaznících, učitelé jsou přesvědčeni o tom, že výuka prostřednictvím globální metody vede na konci 1. tř́ídy a zejména ve druhé třídě ZŠ k nepřesnostem ve čtení. Mnozí žáci nečtou s porozuměním zejména proto, že jednotlivá slova $v$ textu odhadují a nečtou správně obsahově. $Z$ těchto důvodů pak dochází $\mathrm{k}$ nepřesnostem a nesrovnalostem $\mathrm{v}$ přečteném textu. Naopak po správně zvládnuté analytickosyntetické metodě a správné technice čtení žáci, dle slov učitelů elementaristů, vykazují lepší výsledky $\mathrm{v}$ porozumění textu a orientaci $\mathrm{v}$ něm. Po zautomatizování analyticko-syntetické činnosti dochází $\mathrm{k}$ snazší orientaci v kterémkoliv textu a následně i k rychlejšímu vyhledávání informací.

\section{Závěr}

Učitelé $\mathrm{v}$ základních školách i vyšších stupních vzdělávání jsou si vědomi toho, že žáci v České republice vykazují v mezinárodních výzkumech poměrně neutěšené výsledky v oblastech gramotností jako takových, potažmo i v čtenářské gramotnosti.

Učitelé elementaristé jsou si této skutečnosti vědomi a mnoho $\mathrm{z}$ nich $\mathrm{v}$ současné době pracuje na dalším vzdělávání a zdokonalování svých kompetencí v této oblasti. Navštěvují kurzy pro rozvoj čtenářské gramotnosti a pracují zejména na uplatňování nových participačních výukových metod v pedagogické praxi při rozvoji čtenářské gramotnosti svých žáků. Je nutné s rozvojem daných kompetencí začít již v elementární třídě základního vzdělávání a základy pro čtenářskou gramotnost ve formě vnitřní pozitivní motivace ba měly být kladeny již $\mathrm{v}$ preprimárním vzdělávání, tedy v mateřských školách.

Již v primárním vzdělávání je vhodné učit i nejmladší žáky vyhledávat informace prostřednictvím informačních technologií, jak jsme již popsali, nebot' počítačová gramotnost u žáků zajišt'uje i snazší orientaci v předkládaných textech informačního charakteru. Kromě vzdělávacího obsahu lze realizovat $\mathrm{v}$ souladu se ŠVP i některé oblasti průřezových témat jako je mediální výchova či sociální výchova.

Je nezbytně nutné, aby škola vybavila své žáky takovými kompetencemi, které jim usnadní prosadit se $\mathrm{v}$ současné společnosti, nejen $\mathrm{v}$ rámci Evropy, ale na celém světě.

\section{Literatura}

[1]DOLEŽALOVÁ, J. Funkčni gramotnost. Hradec Králové, Gaudeamus 2005. ISBN 807041-115-5.

[2] Kolektiv autorů. Gramotnost ve vzdéláváni: soubor studií. Praha: VÚP, 2011. ISBN 978-8087000-41-0.

[3]CHRÁSKA, M. Metody pedagogického výzkumu. Praha: Grada, 2007. ISBN 978-80-247$1369-4$.

[4] JEŘÁBEK, J., TUPÝ, J.. Rámcový vzdèlávací program pro základni vzdélávání. Praha: VÚP, 2005. ISBN 80-87000-02-1. 
[5] Evropská komise: Výuka čteni v Evropě: souvislosti, politiky a praxe. Brusel, Euridyce. 2011. ISBN 978-92-9201-189-5.

[6] Education, Audiovisual and Culture Executive Agency : P9 Brussels: Eurydice. 2011. ISBN neuvedeno.

[7] WILDOVÁ, R. Počáteční čtenářská gramotnost. In: Spilková, V. a kol. Proměny primárního vzdělávání v ČR. Praha: Portál, 2005. ISBN 80-7178-942-9.
PhDr. Martina Fasnerová, Ph.D.

Katedra primární a preprimání pedagogiky

Pedagogická Fakulta UP v Olomouci

Žižkovo nám. č. 5

77140 Olomouc, ČR

Tel.: +420 585635110

E-mail: martina.fasnerova@ upol.cz

www pracoviště: www.kpv.upol.cz 